\title{
Drinking Water Quality and Public Health of Selected Towns in South Western Nigeria
}

\section{S. O. Dahunsi, H. I. Owamah, T. A. Ayandiran \& S. U. Oranusi}

Water Quality, Exposure and Health ISSN 1876-1658

Water Qual Expo Health DOI 10.1007/s12403-014-0118-6

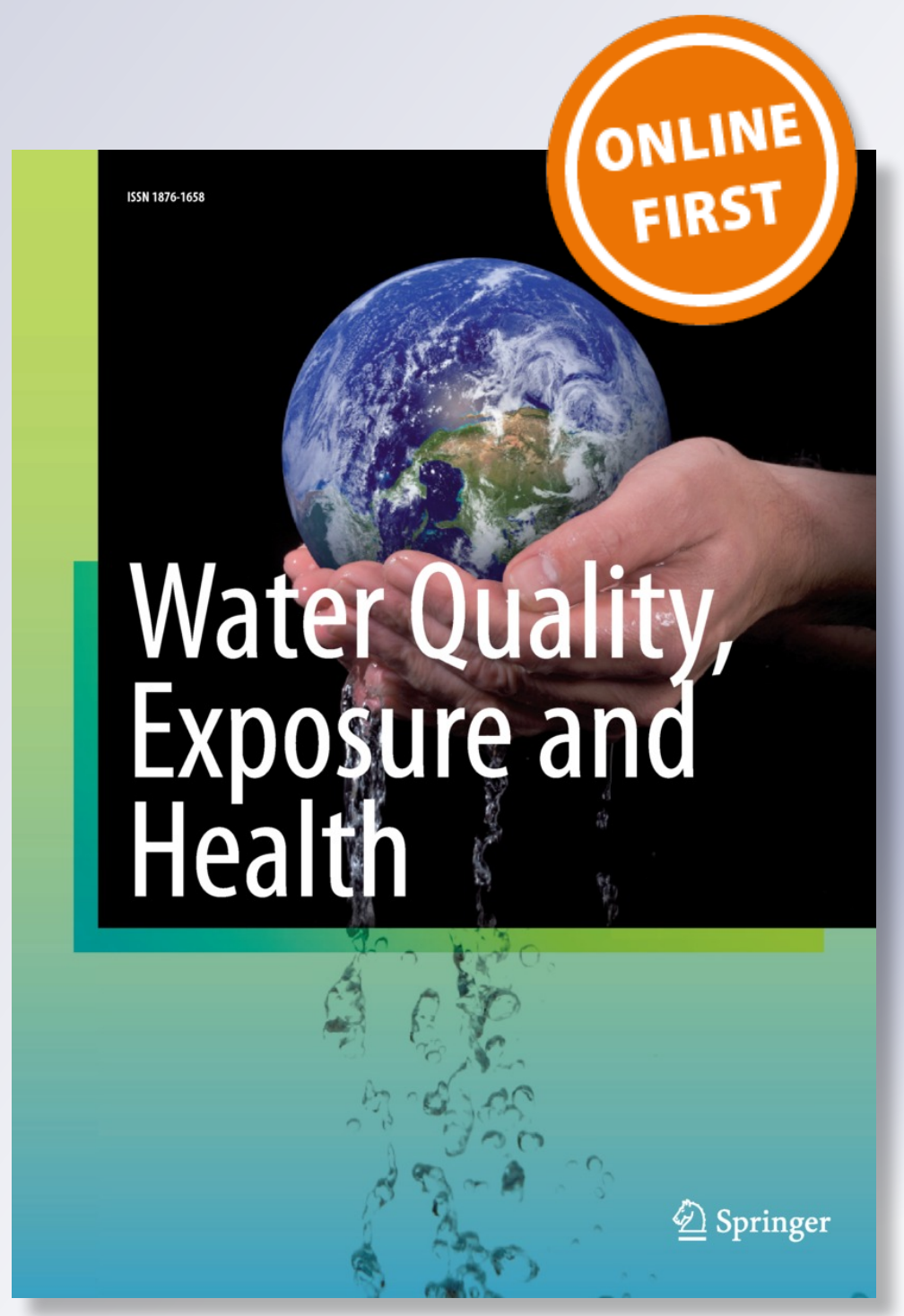

\section{照 Springer}


Your article is protected by copyright and all rights are held exclusively by Springer Science +Business Media Dordrecht. This e-offprint is for personal use only and shall not be selfarchived in electronic repositories. If you wish to self-archive your article, please use the accepted manuscript version for posting on your own website. You may further deposit the accepted manuscript version in any repository, provided it is only made publicly available 12 months after official publication or later and provided acknowledgement is given to the original source of publication and a link is inserted to the published article on Springer's website. The link must be accompanied by the following text: "The final publication is available at link.springer.com". 


\title{
Drinking Water Quality and Public Health of Selected Towns in South Western Nigeria
}

\author{
S. O. Dahunsi - H. I. Owamah - T. A. Ayandiran • \\ S. U. Oranusi
}

Received: 2 October 2013 / Revised: 26 February 2014 / Accepted: 28 February 2014

(C) Springer Science+Business Media Dordrecht 2014

\begin{abstract}
This study was aimed at establishing a water quality database in the study area where none existed previously. Groundwater samples from bore-holes, hand-pump, and hand-dug wells of four densely populated towns in SouthWestern Nigeria were analyzed in respect to physicochemical factors, biological factors, and the metals Nickel (Ni), Lead $(\mathrm{Pb})$, Cadmium $(\mathrm{Cd})$, Zinc $(\mathrm{Zn})$, Copper $(\mathrm{Cu})$, and Iron $(\mathrm{Fe})$ for six consecutive months from September 2012 to February 2013 to give mean values for each town and water source. Total aerobic plate, total coliform bacteria, and Escherichia coli (E. coli) were detected in most of the water samples from the different towns and sources considered. Except for total suspended solids and total solids, the physicochemical parameters of all the samples were within permissible limits. The concentrations $\mathrm{Pb}, \mathrm{Ni}, \mathrm{Cr}$, and $\mathrm{Cd}$ were above the minimum permissible limits. The presence of coliforms and E. coli in the groundwater samples indicates fecal contamination. The microorganisms isolated in this study include Enterobacteriaceae, Staphylococcus aureus, E. coli, Citrobacter, Klebsiella, Pseudomonas, Bacillus, and Micrococcus species. The analysis of variance of data obtained from this study shows
\end{abstract}

S. O. Dahunsi

Department of Biological Sciences, Landmark University,

Omu-Aran, Nigeria

H. I. Owamah $(\bowtie)$

Department of Civil Engineering, Landmark University, P.M.B.1001, Omu-Aran, Nigeria

e-mail: dahilla222@yahoo.com; owamah.hilary@1mu.edu.ng

T. A. Ayandiran

Department of Pure and Applied Biology, Ladoke Akintola

University of Technology, Ogbomosho, Nigeria

S. U. Oranusi

Department of Biological Sciences, Covenant University, Ota,

Ogun State, Nigeria that bore-hole water samples were safer for drinking that water samples from hand-pump, and hand dug wells across the communities.

Keywords Water quality $\cdot$ Metals $\cdot$ Coliform bacteria . Microorganisms $\cdot$ Health

\section{Introduction}

One of the Millennium Development Goals (MDGs) set by the United Nations (UN) is to halve the number of people without access to improved water sources by 2015 (Owamah et al. 2013).The provision of potable water to rural and urban population is necessary to prevent water-borne diseases (Okorafor et al. 2012). The quality and quantity of available water have implications on the health status of a community. According to the UN report, more than 5 million people die annually from diseases caused by drinking contaminated water and lack of adequate sanitation. Increase in human population has exerted enormous pressure on the provision of safe drinking water especially in developing countries (Domènech and Saurí 2011).

The majority of the rural Nigerian populace does not have access to potable water and therefore, depend on raw water from wells, streams and rivers for drinking and other domestic uses (Owamah et al. 2013; Shittu et al. 2009). The principal microbial water-borne diseases are typhoid and paratyphoid fevers (Salmonellosis), cholera, bacillary dysentery (Shigellosis), infectious hepatitis, dracontiasis, schistosomiasis, etc (Udoessien 2003; Ukpong and Okon 2013).

At the moment, there is no form of treated water supply in the area of study. There is also paucity of information on the quality of ground water sources for the major towns of Ogun, and Lagos states that could serve as water quality database for the area. The purpose of this study is to carry out 
Fig. 1 Map of study area

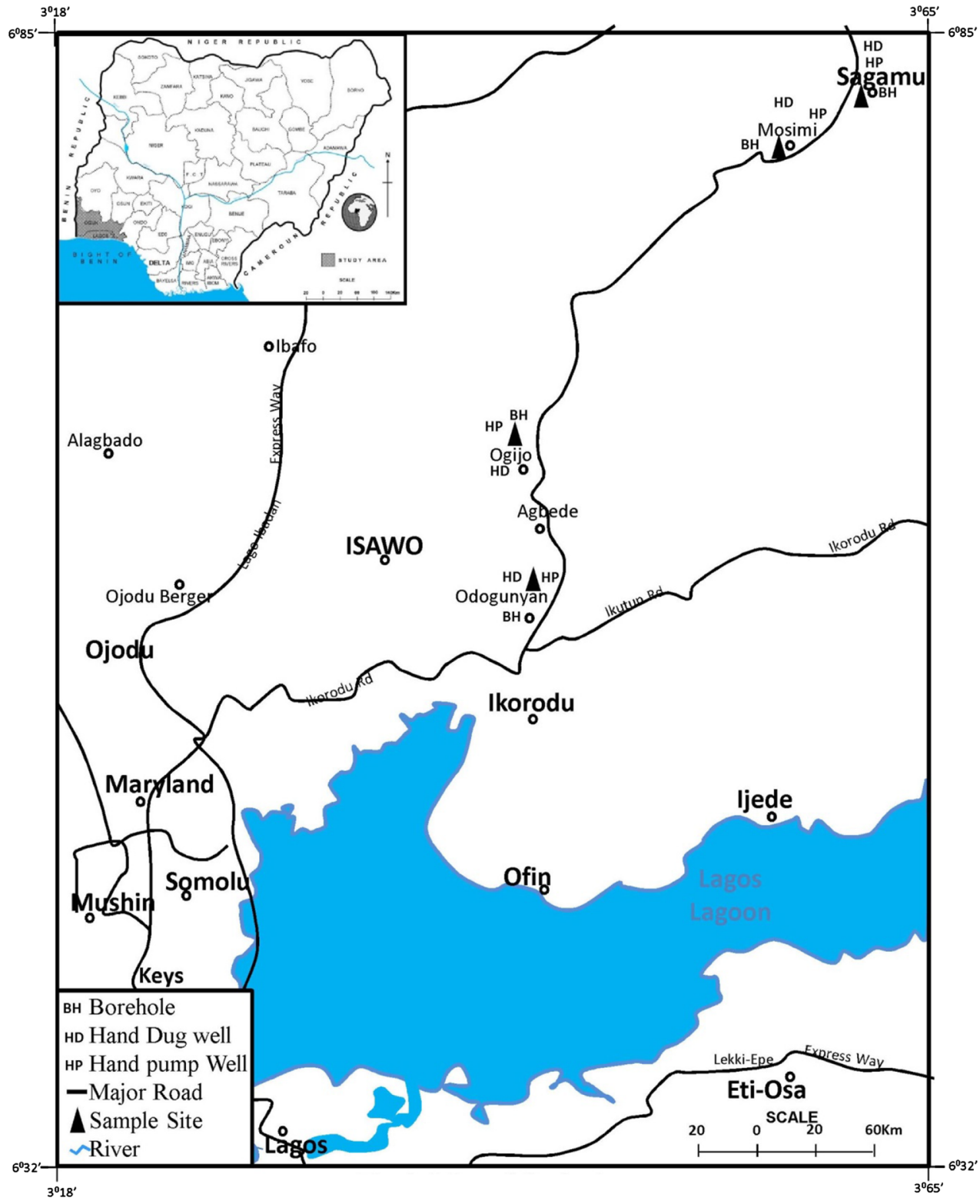

Source: Ministry of Lands, Surveys \& Urban Development, Nigeria, (2008)

detailed investigation into the drinking water quality of the selected towns in the region, in terms of the physicochemical factors, biological factors, and metals. This could then serve as water quality database for the area under study for the possible development sustainable water supply projects for the achievement of MDGs in the sub-region.

\section{Materials and Methods}

Study Area

The study area includes Sagamu, Mosimi, and Ogijo towns in Ogun State and Odogunyan town in Lagos State (Fig. 1).
The population of the study area is approximately five hundred thousand persons. The selected communities are closely interconnected by the major Sagamu-Ikorodu road linking Ogun, and Lagos States. The population of the area of study has been on the increase because of the presence of many industries in the area such as Lafarge cement factory, the Nigerian National Petroleum Corporation (NNPC) major depot, and the PZ Cusson limited in Sagamu, Mosimi, and Odogunyan, respectively. The high population in the case of Ogijo is as a result of its closeness to Lagos metropolis which has made many people working in Lagos State to live in Ogijo. Because of these factors, the towns are polluted with many kinds of wastes such as petroleum products, sewage, solid wastes, etc. The study area is located at about 
$6^{\circ} 42^{\prime} 0^{\prime \prime} \mathrm{N}$ latitude and $3^{\circ} 31^{\prime} 0^{\prime \prime} \mathrm{E}$ longitude. It is characterized by the sub-equatorial climate with two distinct seasons; the rainy or wet season occurring from April to September and the dry or harmattan season occurring from late October to March. The average annual precipitation, monthly temperature means, and relative humidity range of the area of study are $1,300 \mathrm{~mm}, 35^{\circ} \mathrm{C}$, and $80-95 \%$, respectively (Afeni 2008). The natural vegetation is of woodland, grassland with swamp forest in some areas.

\section{Water Sampling}

Water samples were collected from September 01, 2012 to March 01, 2013 from bore-holes (wells with electric pump), hand-pump wells (manually operated pumps), and handdug wells (artificial pumpless wells). New high-density PET screw-capped containers of $1.5 \mathrm{~L}$ capacity were used to collect the water samples. Water from the bore-holes and handpump wells were allowed to run for $5 \mathrm{~min}$, followed by a reduction in the flow of water to allow filling the bottles without splashing. The removal of gases from the bottles was achieved by filling and emptying the bottles before the collection of actual samples. In the case of the hand-dug wells, the well water was first disturbed with a drawing bucket for five consecutive times to allow for proper mixing up of the well water before drawing out the bucket of water for the actual samples. The PET containers and stoppers were thoroughly washed with distilled water for three times and once with the water to be sampled before collecting the actual sample. As was described by Owamah et al. (2013), Khan et al. (2012), at each site, one bottle was filled with water having no acid while the other bottle was filled with the water from the same point and acidified by adding a few drops of $5 \%$ $\mathrm{HNO}_{3}$ to stop the activities of microorganisms. At the same time, samples for microbial analysis were collected using autoclave-sterilized sample bottles from the same locations (Owamah et al. 2013). The water samples were transported to the Central Analysis Laboratory of the International Institute of Tropical Agriculture (IITA), Ibadan, Nigeria. Twelve samples, three from each town, were collected on monthly basis to give a total of 72 raw water samples. The water samples were preserved in a refrigerator at $4{ }^{\circ} \mathrm{C}$ to keep the water content intact until analyses were carried out.

\section{Analytical Procedure}

The parameters of $\mathrm{pH}$ (HI 9024-C, Hanna Instruments, Smithfield, RI, USA), temperature (HI 98517, Hanna Instr.), salinity (HI 19311, Hanna Instr.), electrical conductivity (HI 2315, Hanna Instr.), and total dissolved solids (TDS) (VSI 22 , VSI Electronics Private Limited, Punjab, India) were analyzed in-situ using the mentioned hand digital meters. Dissolved oxygen of the water samples were analyzed using the azide modification of Winkler's method (APHA 1992). As described in APHA (1992), chloride was determined by titration. Ultraviolet spectrophotometer screening method was used in the determination of the major anions by strictly following the method described in APHA (2012) using a UV spectrophotometer (DR 2800, HACH, Washington, USA) (Khan et al. 2012; Owamah et al. 2013). In order to ensure that the analyses were reliable and reproducible, blank, standard, and pre-analyzed samples were analyzed after every 10 samples (Owamah et al. 2013). Standard methods were used to count the total coli form bacteria as most probable number (MPN) in water samples (APHA 2012). Metals were analyzed with atomic absorption spectrophotometer (AAS) (Sens AA 3000, GBC, Australia) following the method in APHA (2012).

\section{Disease Survey}

In order to properly investigate the public health implication of drinking contaminated water on the residents of the area of study, a survey was carried out using structured questionnaires. The survey team consists of three environmental health experts and 10 students undergoing health training. The consent of respondents was sought before commencement of the survey. Respondents were randomly selected, and a total of 2,500 including male and female with at least primary school level of education were involved in the survey. The demographic, habits, and occupational data of the respondents were captured in the questionnaires. Terminologies in the questionnaire that may be difficult to some respondents were explained to them by members of the survey team.

\section{Statistical Analyses}

Microsoft Office Excel 2007 software package was used to statistically analyze data with a significance level of $P<$ 0.05 using the analysis of variance (ANOVA). The mean values of the parameters analyzed were computed for each town and water source. The standard deviations show the variability between samples taken individually.

\section{Results}

Physical Parameters

The physical parameters of the different water sources from the different communities are shown in Table 1. ANOVA shows that there was no significant variation $(P<0.05)$ in the values of the physical parameters. The temperature of the water samples ranged from 19.50 to $29.40^{\circ} \mathrm{C}$. The $\mathrm{pH}$ values ranged from 5.13 to 8.16 and were close to the permissible limits set by the United States Environmental Protec- 
Table 1 The mean values of the physicochemical parameters of water samples in the area of study

\begin{tabular}{|c|c|c|c|c|c|c|c|}
\hline Sample & Temperature $\left({ }^{\circ} \mathrm{C}\right)$ & $\mathrm{pH}$ & $\begin{array}{l}\text { Electrical } \\
\text { conductivity } \\
\left(\mathrm{mS} \mathrm{cm}^{-1}\right)\end{array}$ & $\begin{array}{l}\text { Total dissolved } \\
\text { solids } \\
\left(\mathrm{mg} \mathrm{L}^{-1}\right)\end{array}$ & $\begin{array}{l}\text { Total } \\
\text { suspended } \\
\text { solids } \\
\left(\mathrm{mg} \mathrm{L}^{-1}\right)\end{array}$ & $\begin{array}{l}\text { Total solids } \\
\left(\mathrm{mg} \mathrm{L}^{-1}\right)\end{array}$ & Salinity (\%) \\
\hline \multicolumn{8}{|l|}{ Sagamu } \\
\hline Bore hole $(n=45)$ & $24.50 \pm 0.50$ & $6.20 \pm 0.20$ & $41.37 \pm 0.32$ & $20.33 \pm 0.31$ & $0.10 \pm 0.01$ & $201.43 \pm 0.58$ & $0.02 \pm 0.01$ \\
\hline Hand pump $(n=40)$ & $21.00 \pm 0.30$ & $5.80 \pm 0.10$ & $23.3 \pm 0.44$ & $11.43 \pm 0.40$ & $0.12 \pm 0.15$ & $21.11 \pm 0.01$ & $0.01 \pm 0.01$ \\
\hline Dug well $(n=60)$ & $27.00 \pm 0.40$ & $6.30 \pm 0.26$ & $22.4 \pm 0.53$ & $16.57 \pm 0.51$ & $0.19 \pm 0.01$ & $110.16 \pm 0.02$ & $0.01 \pm 0.01$ \\
\hline \multicolumn{8}{|l|}{ Mosimi } \\
\hline Bore hole $(n=60)$ & $27.00 \pm 0.20$ & $5.80 \pm 0.10$ & $32.37 \pm 0.35$ & $16.23 \pm 0.21$ & $0.21 \pm 0.02$ & $15.47 \pm 0.31$ & $0.01 \pm 0.01$ \\
\hline Hand pump $(n=50)$ & $25.00 \pm 0.20$ & $6.30 \pm 0.26$ & $25.6 \pm 0.53$ & $12.37 \pm 0.47$ & $0.18 \pm 0.01$ & $16.16 \pm 0.02$ & $0.01 \pm 0.01$ \\
\hline Dug well $(n=50)$ & $28.00 \pm 0.30$ & $6.20 \pm 0.26$ & $31.33 \pm 0.42$ & $15.30 \pm 0.26$ & $0.14 \pm 0.01$ & $15.15 \pm 0.02$ & $0.02 \pm 0.01$ \\
\hline \multicolumn{8}{|l|}{ Ogijo } \\
\hline Bore hole $(n=80)$ & $23.00 \pm 0.50$ & $7.76 \pm 0.15$ & $31.40 \pm 0.35$ & $11.23 \pm 0.25$ & $0.08 \pm 0.02$ & $109.04 \pm 0.02$ & $0.01 \pm 0.01$ \\
\hline Hand pump $(n=65)$ & $27.00 \pm 0.20$ & $8.16 \pm 0.21$ & $304.33 \pm 1.53$ & $151.23 \pm 0.25$ & $0.18 \pm 0.01$ & $151.2 \pm 0.01$ & $0.01 \pm 0.01$ \\
\hline Dug well $(n=90)$ & $29.60 \pm 0.20$ & $7.67 \pm 0.16$ & $308.33 \pm 1.53$ & $152.8 \pm 1.11$ & $0.27 \pm 0.02$ & $153.23 \pm 0.02$ & $0.01 \pm 0.01$ \\
\hline \multicolumn{8}{|l|}{ Odogunyan } \\
\hline Bore hole $(n=75)$ & $21.40 \pm 0.20$ & $6.86 \pm 0.21$ & $23.50 \pm 0.23$ & $17.23 \pm 0.23$ & $0.12 \pm 0.11$ & $147.11 \pm 0.10$ & $0.02 \pm 0.01$ \\
\hline Hand pump $(n=80)$ & $23.20 \pm 0.20$ & $7.32 \pm 011$ & $32.61 \pm 1.21$ & $17.24 \pm 1.01$ & $0.18 \pm 0.10$ & $123.23 \pm 0.01$ & $0.02 \pm 0.01$ \\
\hline Dug well $(n=70)$ & $19.50 \pm 0.02$ & $6.54 \pm 0.12$ & $30.01 \pm 0.34$ & $15.98 \pm 0.19$ & $0.18 \pm 0.05$ & $100.98 \pm 0.02$ & $0.01 \pm 0.01$ \\
\hline
\end{tabular}

Results are expressed as mean \pm standard deviation

$D O$ dissolved oxygen

tion Agency (US-EPA), the Canadian drinking water guidelines and the Standard Organization of Nigeria (SON). The highest $\mathrm{pH}$ (8.16) was obtained from the hand-pump water sample in Ogijo while the lowest value (5.13) was obtained from the dug-well water sample in Odogunya. The values for electrical conductivity (EC) of the water samples from the selected towns ranged from 22.4 to $308.33 \mathrm{mS} \mathrm{cm}^{-1}$ and were all within the permissible limits (Table 6). The highest $\mathrm{EC}\left(308.33 \mathrm{mS} \mathrm{cm}^{-1}\right)$ was obtained from the bore-hole water sample from Mosimi while the lowest $\left(22.4 \mathrm{mS} \mathrm{cm}^{-1}\right)$ was obtained from the dug-well water sample from Odogunyan. Values for total dissolved solids (TDS) ranged from 11.23 to $152.8 \mathrm{mg} \mathrm{L}^{-1}$. Both values were obtained from bore-hole samples collected from Ogijo. Similar result was obtained for the total suspended solids (TSS) in which the highest and minimum values were 0.27 and $0.08 \mathrm{mg} \mathrm{L}^{-1}$ obtained from the bore-hole samples in Ogijo. The total solids (TS) values ranged from 15.11 to $201.43 \mathrm{mg} \mathrm{L}^{-1}$. The highest value (201.43 $\mathrm{mg} \mathrm{L}^{-1}$ ) was obtained from the borehole water sample in Sagamu while the lowest $\left(15.11 \mathrm{mg} \mathrm{L}^{-1}\right)$ was obtained from the hand-pump water sample in Ogijo. The salinity values ranged from 0.01 to $0.02 \%$.

\section{Anions}

Table 2 shows the mean concentrations of the major anions obtained from the drinking water samples. $\mathrm{NO}_{3}^{-}$concen- trations ranged from 0.33 to $0.99 \mathrm{mg} \mathrm{L}^{-1}$ and were within the permissible limits set by the US-EPA, Canadian guidelines and $\mathrm{SON}\left(10,45\right.$, and $50 \mathrm{mg} \mathrm{L}^{-1}$, respectively). The $\mathrm{NO}_{3}^{-}$concentrations were significantly higher $(P<0.05)$ in dug-well water samples as compared to hand-pump and bore-hole water samples. The highest concentration of $\mathrm{NO}_{3}^{-}$ $\left(0.99 \mathrm{mg} \mathrm{L}^{-1}\right)$ was obtained from bore-hole water sample in Mosimi while the lowest $\left(0.33 \mathrm{mg} \mathrm{L}^{-1}\right)$ was obtained from borehole water sample in Odogunyan. The concentrations of $\mathrm{Cl}^{-}$were significantly higher $(P<0.05)$ in dugwell water samples as compared to hand-pump and borehole water samples. There was also variations chloride concentration across the towns. Concentrations of $\mathrm{Cl}^{-}$ranged from 1.96 to $9.04 \mathrm{mg} \mathrm{L}^{-1}$ and were within the permissible limits $\left(<251 \mathrm{mg} \mathrm{L}^{-1}\right)$ for the Canadian guidelines and ( $250 \mathrm{mg} \mathrm{L}^{-1}$ ) for SON. The highest concentration of $\mathrm{Cl}^{-}$ (9.04 $\mathrm{m} \mathrm{L}^{-1}$ ) was obtained from borehole water sample in Mosimi while the lowest concentration $\left(1.96 \mathrm{mg} \mathrm{L}^{-1}\right)$ was obtained from dug-well water sample in Ogijo. The concentrations of $\mathrm{SO}_{4}^{2-}$ ranged from 0.86 to $2.34 \mathrm{mg} \mathrm{L}^{-1}$ and are within the permissible limits of $500 \mathrm{mg} \mathrm{L}^{-1}$ by WHO, Canadian guideline, and SON $\left(100 \mathrm{mg} \mathrm{L}^{-1}\right)$. The highest concentration of $\mathrm{SO}_{4}^{2-}\left(2.34 \mathrm{mg} \mathrm{L}^{-1}\right)$ was obtained from the dug-well water sample in Odogunyan while the lowest concentration $\left(0.86 \mathrm{mg} \mathrm{L}^{-1}\right)$ was obtained from dug- well water sample in Ogijo. The concentrations of $\mathrm{PO}_{4}^{2-}$ ranged from 0.05 and $0.94 \mathrm{mg} \mathrm{L}^{-1}$ with the highest value of $0.94 \mathrm{mg} \mathrm{L}^{-1}$ 
Table 2 The mean concentrations of anions $\left(\mathrm{mg} \mathrm{L}^{-1}\right.$ ) of the water samples in the area of study
Results are expressed as mean \pm standard deviation

\begin{tabular}{lllll}
\hline Sample & Nitrate $\left(\mathrm{NO}_{3}^{-}\right)$ & Chloride $\left(\mathrm{Cl}^{-}\right)$ & Sulfate $\left(\mathrm{SO}_{4}^{2-}\right)$ & Phosphate $\left(\mathrm{PO}_{4}^{2-}\right)$ \\
\hline Sagamu & & & & \\
$\quad$ Bore hole $(n=45)$ & $0.87 \pm 0.01$ & $2.96 \pm 0.17$ & $1.64 \pm 0.01$ & $0.10 \pm 0.02$ \\
Hand pump $(n=40)$ & $0.38 \pm 0.01$ & $2.69 \pm 0.53$ & $1.02 \pm 0.03$ & $0.05 \pm 0.01$ \\
$\quad$ Dug well $(n=60)$ & $0.43 \pm 0.06$ & $2.10 \pm 0.10$ & $0.95 \pm 0.04$ & $0.08 \pm 0.02$ \\
Mosimi & & & & \\
Bore hole $(n=60)$ & $0.39 \pm 0.06$ & $3.24 \pm 0.09$ & $1.68 \pm 0.02$ & $0.06 \pm 0.04$ \\
Hand pump $(n=50)$ & $0.49 \pm 0.01$ & $4.39 \pm 0.20$ & $1.09 \pm 0.01$ & $0.89 \pm 0.01$ \\
$\quad$ Dug well $(n=50)$ & $0.57 \pm 0.02$ & $1.96 \pm 0.05$ & $0.86 \pm 0.03$ & $0.14 \pm 0.04$ \\
Ogijo & & & & \\
$\quad$ Bore hole $(n=80)$ & $0.99 \pm 0.01$ & $3.34 \pm 0.13$ & $1.91 \pm 0.07$ & $0.94 \pm 0.03$ \\
Hand pump $(n=65)$ & $1.85 \pm 0.03$ & $6.66 \pm 0.15$ & $1.74 \pm 0.02$ & $1.24 \pm 0.05$ \\
$\quad$ Dug-well $(n=90)$ & $1.54 \pm 0.03$ & $9.04 \pm 0.03$ & $1.02 \pm 0.01$ & $0.11 \pm 0.02$ \\
Odogunyan & & & & \\
Bore hole $(n=75)$ & $0.91 \pm 0.01$ & $2.32 \pm 0.02$ & $1.23 \pm 0.02$ & $1.11 \pm 0.02$ \\
$\quad$ Hand pump $(n=80)$ & $0.65 \pm 0.03$ & $3.89 \pm 0.21$ & $1.10 \pm 0.01$ & $0.09 \pm 0.02$ \\
Dug well $(n=70)$ & $0.78 \pm 0.02$ & $6.18 \pm 0.24$ & $2.34 \pm 0.02$ & $0.13 \pm 0.01$ \\
\hline
\end{tabular}

Table 3 The mean concentrations of dissolved heavy metals $\left(\mathrm{mg} \mathrm{L}^{-1}\right)$ of water samples in the area of study

\begin{tabular}{llllllll}
\hline Sample & Lead $(\mathrm{Pb})$ & Iron $(\mathrm{Fe})$ & Copper $(\mathrm{Cu})$ & Zinc $(\mathrm{Zn})$ & Nickel $(\mathrm{Ni})$ & Total Chromium $(\mathrm{Cr})$ & Cadmium $(\mathrm{Cd})$ \\
\hline Sagamu & & & & & & & \\
Bore hole $(n=45)$ & $\mathbf{0 . 1 8} \pm \mathbf{0 . 0 1}$ & $0.04 \pm 0.02$ & $0.02 \pm 0.01$ & $0.28 \pm 0.02$ & $\mathbf{0 . 4 8} \pm \mathbf{0 . 0 2}$ & $\mathbf{0 . 2 6} \pm \mathbf{0 . 0 2}$ & $\mathbf{1 . 1 4} \pm \mathbf{0 . 0 5}$ \\
Hand-pump well $(n=40)$ & $\mathbf{0 . 1 5} \pm \mathbf{0 . 0 4}$ & $0.02 \pm 0.01$ & $0.24 \pm 0.01$ & $0.07 \pm 0.02$ & $\mathbf{0 . 4 6} \pm \mathbf{0 . 0 3}$ & $\mathbf{0 . 2 4} \pm \mathbf{0 . 0 3}$ & $\mathbf{1 . 0 9} \pm \mathbf{0 . 0 1}$ \\
Hand-dug well $(n=60)$ & $0.04 \pm 0.04$ & $0.02 \pm 0.01$ & $0.08 \pm 0.02$ & $0.05 \pm 0.01$ & $\mathbf{0 . 4 4} \pm \mathbf{0 . 0 2}$ & $\mathbf{0 . 3 5} \pm \mathbf{0 . 0 3}$ & $\mathbf{1 . 1 2} \pm \mathbf{0 . 0 6}$ \\
Mosimi & & & & & & & \\
Bore hole $(n=60)$ & $\mathbf{0 . 2 3} \pm \mathbf{0 . 0 4}$ & $0.08 \pm 0.02$ & $0.09 \pm 0.02$ & $0.07 \pm 0.02$ & $\mathbf{0 . 6 4} \pm \mathbf{0 . 0 3}$ & $\mathbf{0 . 2 7} \pm \mathbf{0 . 0 1}$ & $\mathbf{1 . 5 5} \pm \mathbf{0 . 0 2}$ \\
Hand-pump well $(n=50)$ & $\mathbf{0 . 2 5} \pm \mathbf{0 . 0 2}$ & $0.09 \pm 0.02$ & $0.11 \pm 0.02$ & $0.06 \pm 0.03$ & $\mathbf{1 . 2 7} \pm \mathbf{0 . 0 3}$ & $\mathbf{0 . 4 1} \pm \mathbf{0 . 0 1}$ & $\mathbf{3 . 1 1} \pm \mathbf{0 . 0 2}$ \\
Hand-dug well $(n=50)$ & $\mathbf{0 . 2 8} \pm \mathbf{0 . 0 2}$ & $0.09 \pm 0.02$ & $0.12 \pm 0.02$ & $0.06 \pm 0.02$ & $\mathbf{0 . 4 6} \pm \mathbf{0 . 0 4}$ & $\mathbf{0 . 3 6} \pm \mathbf{0 . 0 3}$ & $\mathbf{1 . 1 0} \pm \mathbf{0 . 0 2}$ \\
Ogijo & & & & & & & \\
Bore hole $(n=80)$ & $\mathbf{0 . 2 6} \pm \mathbf{0 . 0 3}$ & $0.04 \pm 0.01$ & $0.04 \pm 0.01$ & $0.07 \pm 0.02$ & $\mathbf{0 . 7 4} \pm \mathbf{0 . 0 3}$ & $\mathbf{0 . 4 1} \pm \mathbf{0 . 0 1}$ & $\mathbf{1 . 7 4} \pm \mathbf{0 . 0 5}$ \\
Hand-pump well $(n=65)$ & $\mathbf{0 . 2 9} \pm \mathbf{0 . 0 2}$ & $0.08 \pm 0.02$ & $0.07 \pm 0.01$ & $0.28 \pm 0.02$ & $\mathbf{2 . 7 7} \pm \mathbf{0 . 0 3}$ & $\mathbf{2 . 5 9} \pm \mathbf{0 . 0 2}$ & $\mathbf{3 . 3 0} \pm \mathbf{0 . 4 3}$ \\
Hand-dug well $(n=90)$ & $\mathbf{0 . 2 8} \pm \mathbf{0 . 0 4}$ & $0.06 \pm 0.01$ & $0.09 \pm 0.01$ & $0.25 \pm 0.02$ & $\mathbf{1 . 2 3} \pm \mathbf{0 . 0 1}$ & $\mathbf{2 . 2 2} \pm \mathbf{0 . 3 9}$ & $\mathbf{4 . 0 9} \pm \mathbf{0 . 6 6}$ \\
Odogunyan & & & & & & & \\
Bore hole $(n=75)$ & $\mathbf{0 . 1 6} \pm \mathbf{0 . 0 1}$ & $0.09 \pm 0.01$ & $0.03 \pm 0.02$ & $0.11 \pm 0.01$ & $\mathbf{0 . 8 1} \pm \mathbf{0 . 0 1}$ & $\mathbf{1 . 1 2} \pm \mathbf{0 . 0 3}$ & $\mathbf{1 . 0 9} \pm \mathbf{0 . 0 3}$ \\
Hand-pump well $(n=80)$ & $\mathbf{0 . 2 4} \pm \mathbf{0 . 0 3}$ & $0.10 \pm 0.02$ & $0.07 \pm 0.02$ & $0.12 \pm 0.01$ & $\mathbf{0 . 9 0} \pm \mathbf{0 . 0 1}$ & $\mathbf{0 . 9 0} \pm \mathbf{0 . 0 3}$ & $\mathbf{0 . 7 6} \pm \mathbf{0 . 0 2}$ \\
Hand-dug well $(n=70)$ & $\mathbf{0 . 1 9} \pm \mathbf{0 . 0 1}$ & $0.06 \pm 0.01$ & $0.08 \pm 0.01$ & $0.10 \pm 0.01$ & $\mathbf{0 . 5 4} \pm \mathbf{0 . 0 2}$ & $\mathbf{0 . 5 9} \pm \mathbf{0 . 0 1}$ & $\mathbf{1 . 2 6} \pm \mathbf{0 . 0 3}$ \\
\hline
\end{tabular}

Results are expressed as mean \pm standard deviation, values that exceed standard limits are highlighted

as was obtained in the bore-hole water sample from Mosini while the lowest concentration $\left(0.05 \mathrm{mg} \mathrm{L}^{-1}\right)$ was obtained from hand-pump water sample in Odogunyan.

Metals

Table 3 shows the mean concentrations of the metals in the various water samples. $\mathrm{Pb}$ concentration was significantly $(P<0.05)$ higher in Mosimi and Sagamu as compared to
Odogunyan and Ogijo. The concentrations obtained for $\mathrm{Pb}$ ranged from 0.04 to $0.29 \mathrm{mg} \mathrm{L}^{-1}$ and were above the permissible limits of WHO, US-EPA, Canadian guideline, and SON. The highest concentration of $\mathrm{Pb}\left(0.29 \mathrm{mg} \mathrm{L}^{-1}\right)$ was obtained from hand-pump water sample in Odogunyan while the lowest concentration $\left(0.04 \mathrm{mg} \mathrm{L}^{-1}\right)$ was obtained from bore-hole water sample in Odogunyan. Fe concentrations ranged from 0.10 to $0.02 \mathrm{mg} \mathrm{L}^{-1}$ and were within permissible limits (Table 6). The highest $\left(0.10 \mathrm{mg} \mathrm{L}^{-1}\right)$ and low- 
Table 4 Microbial profile of the water samples in the area of study

Results are expressed as mean \pm standard deviation, values that exceed standard limits are highlighted $N D$ not detected

\begin{tabular}{lrll}
\hline Sample & $\begin{array}{l}\text { Total aerobic plate } \\
\text { count }\left(\mathrm{cfu} 100 \mathrm{~mL}^{-1}\right)\end{array}$ & $\begin{array}{l}\text { Total coliform count } \\
\left(\mathrm{cfu} 100 \mathrm{~mL}^{-1}\right)\end{array}$ & E. coli $\left(\mathrm{cfu} 100 \mathrm{~mL}^{-1}\right)$ \\
\hline Sagamu & & & \\
Bore-hole $(n=45)$ & $8.00 \pm 1.00$ & $\mathrm{ND}$ & $\mathrm{ND}$ \\
Hand-pump well $(n=40)$ & $\mathbf{1 1 6 . 0 0} \pm \mathbf{2 . 0 0}$ & $5.00 \pm 1.00$ & $\mathbf{1 1 . 0 0} \pm \mathbf{1 . 0 0}$ \\
Hand-dug well $(n=60)$ & $2.00 \pm 1.00$ & $\mathrm{ND}$ & $\mathrm{ND}$ \\
Mosimi & & & \\
Bore hole $(n=60)$ & $\mathbf{1 3 5 . 0 0} \pm \mathbf{1 . 0 0}$ & $\mathrm{ND}$ & $\mathrm{ND}$ \\
Hand-pump $(n=50)$ & $13.00 \pm 1.00$ & $\mathrm{ND}$ & $\mathrm{ND}$ \\
Hand-dug well $(n=50)$ & $\mathbf{1 3 6 . 0 0} \pm \mathbf{1 . 0 0}$ & $\mathbf{6 . 0 0} \pm \mathbf{1 . 0 0}$ & $\mathbf{8 . 0 0} \pm \mathbf{1 . 0 0}$ \\
Ogijo & & & $\mathrm{ND}$ \\
Bore hole $(n=80)$ & $12.00 \pm 1.00$ & $\mathrm{ND}$ & $\mathrm{ND}$ \\
Hand-pump well $(n=65)$ & $82.00 \pm 1.00$ & $\mathrm{ND}$ & $\mathbf{1 0 . 0 0} \pm \mathbf{1 . 0 0}$ \\
Hand-dug well $(n=90)$ & $\mathbf{1 0 2 . 0 0} \pm \mathbf{1 . 0 0}$ & $\mathbf{1 5 . 0 0} \pm \mathbf{1 . 0 0}$ & $\mathrm{ND}$ \\
Odogunyan & & & $\mathbf{8 . 0 0} \pm \mathbf{1 . 0 0}$ \\
Bore hole $(n=75)$ & $12.00 \pm 1.00$ & $\mathrm{ND}$ & $\mathbf{1 1 . 0 0} \pm \mathbf{1 . 0 0}$ \\
Hand-pump well $(n=80)$ & $52.00 \pm 1.00$ & $\mathbf{6 . 2 . 0 0} \pm \mathbf{1 . 0 0}$ & \\
Hand dug well $(n=70)$ & $43.00 \pm 1.00$ & $\mathbf{7 . 0 0} \pm \mathbf{1 . 0 0}$ & \\
\hline
\end{tabular}

est $\left(0.020 .10 \mathrm{mg} \mathrm{L}^{-1}\right)$ concentrations of Fe were obtained from hand-pump and dug-well water samples in Odogunyan, respectively.

The concentrations of $\mathrm{Cu}$ ranged from 0.02 to $0.24 \mathrm{mg} \mathrm{L}^{-1}$ and were within the permissible limits of the WHO (2.0 $\left.\mathrm{mg} \mathrm{L}^{-1}\right)$, US-EPA (1.30 $\left.\mathrm{mg} \mathrm{L}^{-1}\right)$, Canadian guidelines (1.0 $\left.\mathrm{mg} \mathrm{L}^{-1}\right)$, and SON (1.0 $\left.\mathrm{mg} \mathrm{L}^{-1}\right)$.

The highest concentration of $\mathrm{Cu}\left(0.24 \mathrm{mg} \mathrm{L}^{-1}\right)$ was obtained from hand-pump water sample in Sagamu while the lowest $\left(0.02 \mathrm{mg} \mathrm{L}^{-1}\right)$ was obtained from bore-hole water samples in Odogunyan and Sagamu. Zn concentrations ranged from 0.05 to $0.28 \mathrm{mg} \mathrm{L}^{-1}$ and were within permissible limits (Table 6). The highest concentration of $\mathrm{Zn}$ $\left(0.28 \mathrm{mg} \mathrm{L}^{-1}\right)$ was obtained from bore-hole and hand-pump water samples in Mosimi while the lowest $\left(0.05 \mathrm{mg} \mathrm{L}^{-1}\right)$ was obtained from the dug-well water sample in Odogunyan. Concentrations of Ni ranged from 0.44 to $2.77 \mathrm{mg} \mathrm{L}^{-1}$. These concentrations were above the WHO permissible limit (0.02 $\left.\mathrm{mg} \mathrm{L}^{-1}\right)$ for drinking water. The highest concentration ( $2.77 \mathrm{mg} \mathrm{L}^{-1}$ ) was obtained from the hand-pump water sample in Mosimi while the lowest concentration $\left(0.44 \mathrm{mg} \mathrm{L}^{-1}\right)$ was obtained from dug-well water sample in Odgunyan. In the study area, there was no significant variation $(P<0.05)$ in $\mathrm{Cr}$ concentrations detected in the different drinking water sources.

The concentrations of $\mathrm{Cr}$, ranged from 0.24 to $2.59 \mathrm{mg} \mathrm{L}^{-1}$ and exceeded the permissible limits of WHO, Canadian guideline, US-EPA, and SON (Table 6) for drinking water. The highest $\mathrm{Cr}$ concentration $\left(2.59 \mathrm{mg} \mathrm{L}^{-1}\right)$ was obtained from hand -pump water sample in Mosimi while the lowest $\left(0.24 \mathrm{mg} \mathrm{L}^{-1}\right)$ was obtained from hand-pump water sample in Odogunyan. Concentrations of $\mathrm{Cd}$ ranged from 0.10 to $4.09 \mathrm{mg} \mathrm{L}^{-1}$ which exceed the WHO and SON (0.0030 $\left.\mathrm{mg} \mathrm{L}^{-1}\right)$, US-EPA and Canadian guidelines $\left(0.005 \mathrm{mg} \mathrm{L}^{-1}\right)$ permissible limits for drinking water. The highest and lowest concentrations for $\mathrm{Cd}$ (4.09 and $0.18 \mathrm{mg} \mathrm{L}^{-1}$ ) were obtained from bore-hole water samples in Mosimi and Sagamu.

\section{Microbial Contamination}

The result of the microbial analysis of the water samples is shown in Table 4. The different water sources in the area of study had high concentration of total aerobic plate count. The highest mean total aerobic plate count of $136 \mathrm{cfu} \mathrm{mL}^{-1}$ was obtained in the dug-well water sample in Ogijo. The minimum total aerobic plate count of $2 \mathrm{cfu} \mathrm{mL}^{-1}$ was obtained in the dug-well water sample in Sagamu. Total coliform bacteria were only detected in the hand-pump and dug-well water samples in the area of study. The maximum total coliform count of $15 \mathrm{cfu} \mathrm{mL}^{-1}$ was found in the hand-pump water sample of Mosimi. E. coli was detected in Odogunyan (hand-pump well), Ogijo (hand-dug-well), Mosimi (handdug-well) and Sagamu (hand-pump, and dug-wells) water samples. These biological contaminations are attributable to the closeness of water wells to septic tanks and open-dumps in the area. It is therefore necessary for the responsible agen- 
Table 5 Disease report during health survey

\begin{tabular}{lrlll}
\hline Parameters & Sagamu & Mosimi & Ogijo & Odogunyan \\
\hline Demographic & & & & \\
Male (adult) & 560 & 620 & 850 & 700 \\
Female (adult) & 980 & 765 & 1,120 & 1,300 \\
Male (children) & 520 & 432 & 568 & 701 \\
Female (children) & 649 & 460 & 940 & 905 \\
Health-based (\%) & & & & \\
Hepatitis A & 15 & 14 & 20 & 17 \\
Hepatitis B & 8 & 13 & 16 & 14 \\
Hepatitis C & 10 & 10 & 12 & 8 \\
Cholera & 18 & 23 & 19 & 30 \\
Typhoid & 10 & 16 & 37 & 20 \\
Diarrhea & 20 & 14 & 15 & 16 \\
Anemia & 14 & 13 & 3 & 18 \\
Dysentery & 22 & 17 & 23 & 19 \\
Cancer & 1 & 2.5 & 1.8 & 4.1 \\
Gastroenteritis & 14 & 13 & 18 & 13 \\
Sleeping challenge & 31 & 30 & 41 & 42 \\
Poor appetite & 23 & 28 & 51 & 20 \\
Constipation & 18 & 46 & 31 & 42 \\
Vomiting & 18 & 21 & 10 & 36 \\
Malaria & 12 & 16 & 32 & 41 \\
Pneumonia & 2 & 10 & 31 & 4 \\
Skin diseases & 8 & 4 & 6 & 1 \\
Nausea & 3 & 7 & 10 & 13 \\
\hline & & & & \\
\hline
\end{tabular}

cies to consider the provision of potable water in the area of study a top priority.

\section{Health Challenges}

The summary of the health challenges reported by respondents during the survey conducted in this research is shown in Table 5. Hepatitis A, B, and C were reported by 14-20, $8-16$, and $8-12 \%$ of the respondents, respectively. Cholera was reported by $18-30 \%$ of the respondents, diarrhea by $14-20 \%$ of the respondents, gastroenteritis by $33-44 \%$ of the respondents, typhoid by $10-37 \%$ while dysentery was reported by $17-23 \%$ of the respondents. Other health problems reported by less than $3 \%$ of the respondents include anemia, cancer, sleeping disorder, poor/loss of appetite, constipation, vomiting/nausea, and malaria.

\section{Discussion}

In the area of study, the inhabitants range from middle to low income earners most of whom cannot afford the luxury of treated (bottled) water with only few being able to
Table 6 Drinking water guidelines by different organizations

\begin{tabular}{|c|c|c|c|c|}
\hline Contaminant & WHO & US & Canadian & SON \\
\hline Cadmium, $\mathrm{Cd}\left(\mathrm{mg} \mathrm{L}^{-1}\right)$ & 0.003 & 0.005 & 0.005 & 0.003 \\
\hline Chloride, $\mathrm{Cl}\left(\mathrm{mg} \mathrm{L}^{-1}\right)$ & - & - & $<251$ & 250 \\
\hline Chromium, $\mathrm{Cr}\left(\mathrm{mg} \mathrm{L}^{-1}\right)$ & 0.050 & 0.010 & 0.050 & 0.050 \\
\hline Copper, $\mathrm{Cu}\left(\mathrm{mg} \mathrm{L}^{-1}\right)$ & 2.000 & 1.300 & 1.000 & 1.000 \\
\hline Iron, $\mathrm{Fe}\left(\mathrm{mg} \mathrm{L}^{-1}\right)$ & - & 0.300 & 0.300 & 0.300 \\
\hline Lead, $\mathrm{Pb}\left(\mathrm{mg} \mathrm{L}^{-1}\right)$ & 0.001 & 0 & 0.010 & 0.010 \\
\hline Zinc, $\mathrm{Zn}\left(\mathrm{mg} \mathrm{L}^{-1}\right)$ & - & 5.000 & 5.000 & 3.000 \\
\hline Nickel, Ni (mg L $\left.{ }^{-1}\right)$ & 0.020 & - & - & 0.020 \\
\hline Nitrate, $\mathrm{NO}_{3}^{-}\left(\mathrm{mg} \mathrm{L}^{-1}\right)$ & - & 10.000 & 45.000 & 50.000 \\
\hline $\mathrm{pH}$ & - & $6.5-8.5$ & $6.5-8.5$ & $6.5-8.5$ \\
\hline Sulfate, $\mathrm{SO}_{4}^{2-}\left(\mathrm{mg} \mathrm{L}^{-1}\right)$ & 500 & - & 500 & 100 \\
\hline $\begin{array}{l}\text { Total coliform } \\
\left(\text { cfu } 100 \mathrm{~mL}^{-1}\right)\end{array}$ & 0 & 5.0 & 0 & 10 \\
\hline $\begin{array}{l}\text { Total aerobic plate count } \\
\left(\text { cfu } 100 \mathrm{~mL}^{-1}\right)\end{array}$ & 100 & - & - & - \\
\hline $\begin{array}{l}\text { E. coli count } \\
\quad\left(\mathrm{cfu} 100 \mathrm{~mL}^{-1}\right)\end{array}$ & 0 & - & - & - \\
\hline $\begin{array}{l}\text { Electrical conductivity, } \\
\mathrm{EC}\left(\mathrm{mS} \mathrm{cm}^{-1}\right)\end{array}$ & 1,000 & - & - & 1,000 \\
\hline $\begin{array}{l}\text { Total suspended solids, } \\
\text { TSS }\left(\mathrm{mg} \mathrm{L}^{-1}\right)\end{array}$ & - & - & - & - \\
\hline $\begin{array}{l}\text { Total solids, TS } \\
\left(\mathrm{mg} \mathrm{L}^{-1}\right)\end{array}$ & - & - & - & - \\
\hline $\begin{array}{l}\text { Total dissolved solids, } \\
\text { TDS }\left(\mathrm{mg} \mathrm{L}^{-1}\right)\end{array}$ & 500 & - & - & 500 \\
\hline Salinity $(\%)$ & - & - & - & - \\
\hline
\end{tabular}

buy sachet-packaged drinking water(popularly called "pure water in Nigeria") occasionally. This has made them to rely on water from bore-holes, hand-pumps, and dug-wells. Many of these wells are shallow (not reaching the standard depth), and thus, the water from them is not of satisfactory quality as against the general speculations by the people that groundwater is safe and free from contaminations. Many physicochemical and biological factors are responsible for the change in water quality and disease incidence as were previously reported (Tamasi and Cini 2004; Mora et al. 2009).

The $\mathrm{pH}$ values in this study are in compliance with permissible limits (Table 6) and as such do not pose any effect on the consumers. Anions in this study are within the permissible limits stipulated by regulatory bodies (Table 6). Anions are generally known to play important roles in the quality of drinking water and human health (Khan et al. 2012; Owamah et al. 2013).

In the area under study, metal concentrations vary as some are within the permissible limits while others exceed the limits at alarming levels. Groundwater sources in the area of study had $\mathrm{Pb}, \mathrm{Cd}, \mathrm{Ni}$, and $\mathrm{Cr}$ concentrations above the permissible limits. Generally, a higher level of metal contamination was detected in Ogijo and Odogunyan that are more industrialized. 

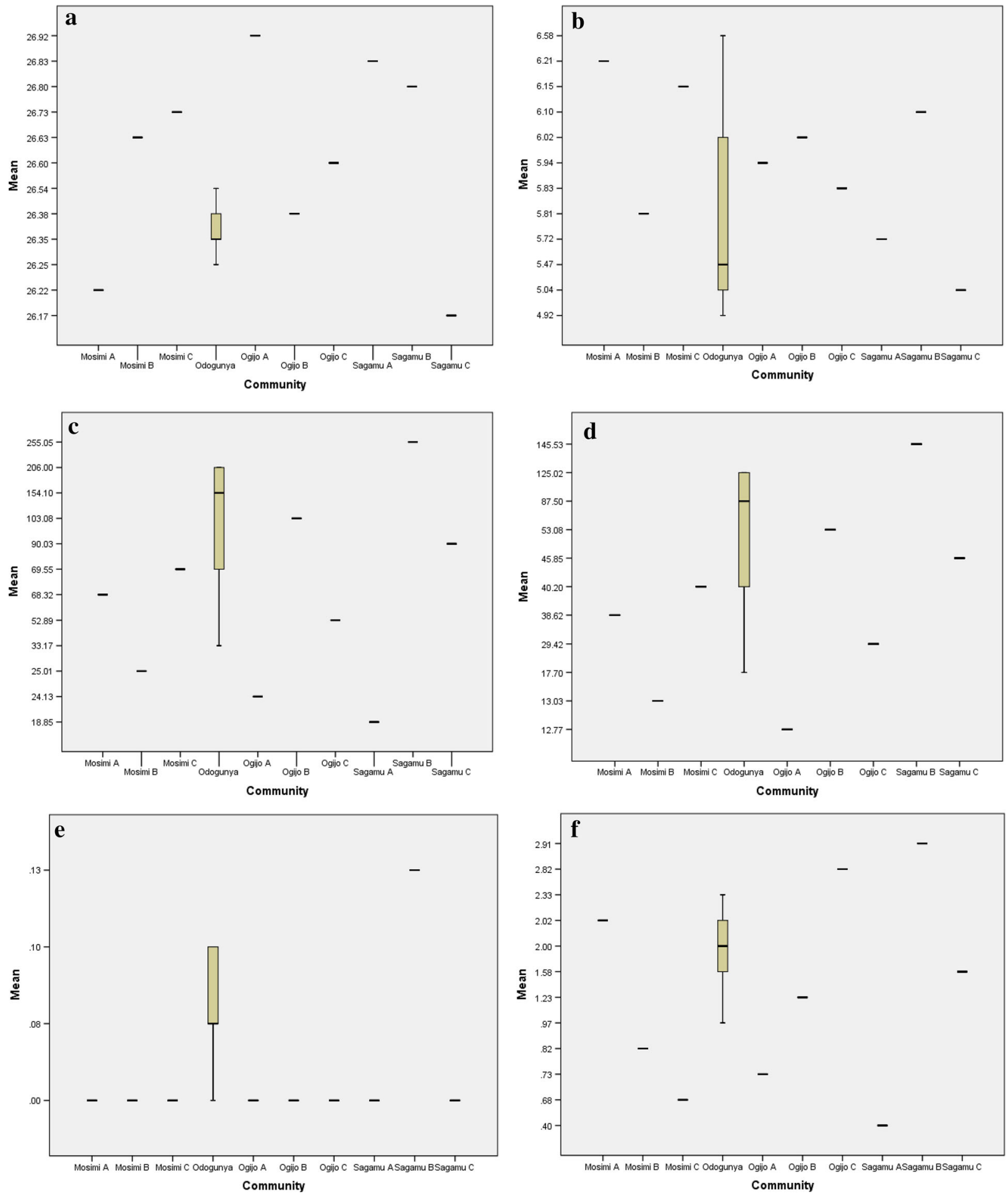

Fig. 2 a Mean temperature $\left({ }^{0} \mathrm{C}\right)$ values of water samples from the various communities, $\mathbf{b}$ Mean $\mathrm{pH}$ values of water samples from the various communities, $\mathbf{c}$ Mean electrical conductivity $\left(\mu \mathrm{S} \mathrm{cm}^{-1}\right)$ values of water samples from the various communities, $\mathbf{d}$ Mean total dissolved solids $\left(\mathrm{mg} \mathrm{L}^{-1}\right)$ values of water samples from the various communities, e Mean total suspended solids $\left(\mathrm{mg} \mathrm{L}^{-1}\right)$ values of water samples from the various communities, $\mathbf{f}$ Mean salinity $(\%)$ values of water samples from the various communities, $\mathbf{g}$ Mean nitrate $\left(\mathrm{mg} \mathrm{L}^{-1}\right)$ values of water samples from the various communities, $\mathbf{h}$ Mean chloride

(mg L $\mathrm{L}^{-1}$ ) values of water samples from the various communities, $\mathbf{i}$ Mean sulfate $\left(\mathrm{mg} \mathrm{L}^{-1}\right)$ values of water samples from the various communities, j Mean phosphate $\left(\mathrm{mg} \mathrm{L}^{-1}\right)$ values of water samples from the various communities, $\mathbf{k}$ Mean zinc $\left(\mathrm{mg} \mathrm{L}^{-1}\right)$ values of water samples from the various communities, 1 Mean cadmium $\left(\mathrm{mg} \mathrm{L}^{-1}\right)$ values of water samples from the various communities, $\mathbf{m}$ Mean nickel $\left(\mathrm{mg} \mathrm{L}^{-1}\right)$ values of water samples from the various communities, $\mathbf{n}$ Mean total chromium $\left(\mathrm{mg} \mathrm{L}^{-1}\right)$ values of water samples from the various communities 

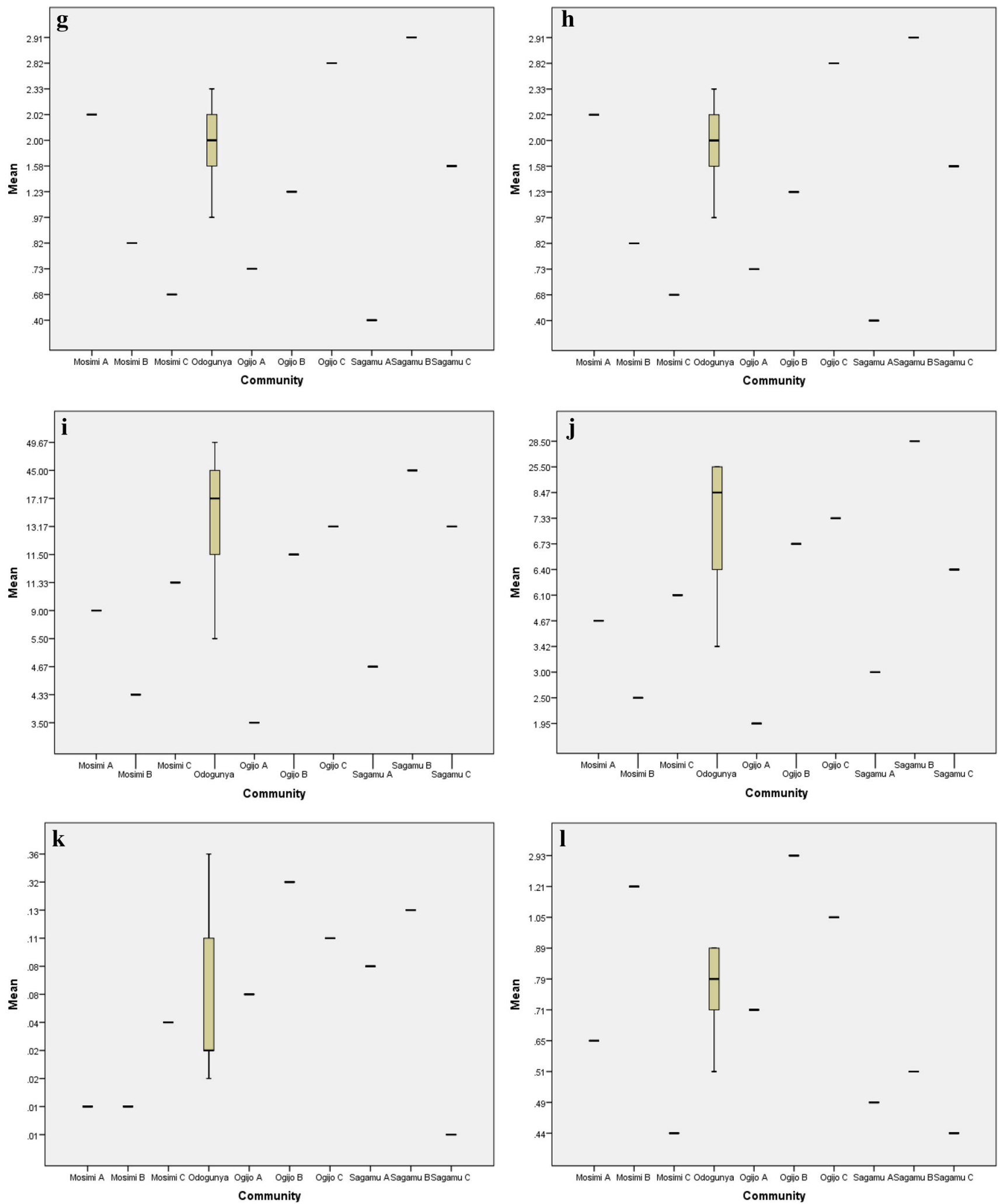

Fig. 2 continued 

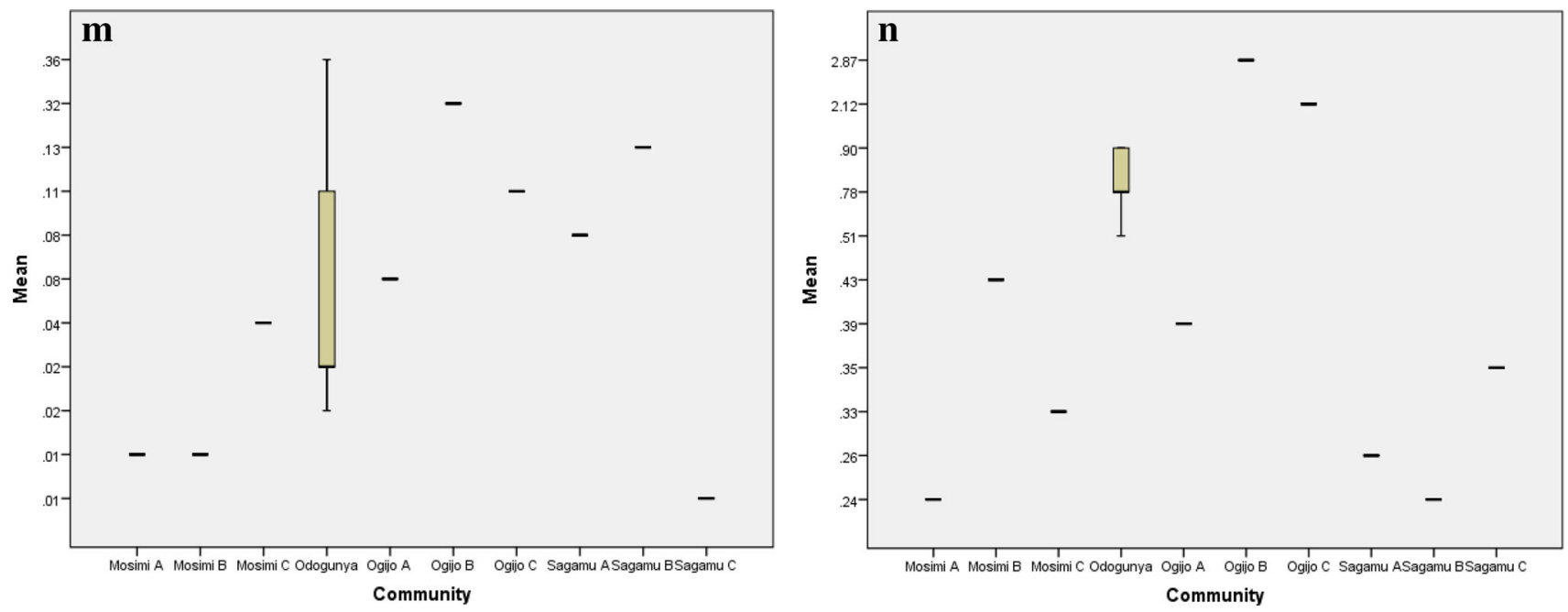

Fig. 2 continued

After ingestion through food and water, $\mathrm{Pb}$ usually accumulates in the skeleton where it causes health defects which include sub-encephalopathic, neurological, and behavioral effects (WHO 1993; WHO 1996; WHO 2006). Pb when present in the food chain can result in bioaccumulation, thereby becoming harmful to man's health (Owamah 2013; Dahunsi et al. 2012). Ni concentrations were high in the water samples from the industrialized areas in this study. Sources of Ni may include steel alloy, electronics components, sinks, and utensils. Ni exposure through drinking water can cause allergy and skin eczema. About 3-8\% of the respondents suffer from skin diseases which may be linked to $\mathrm{Ni}$ exposure. Cd contamination was observed to be prevalent in Ogijo which could be associated with petroleum and other anthropogenic activities in the area. $\mathrm{Cd}$ exposure causes health disorders like nausea, vomiting, diarrhea, muscle cramps, sensory disturbances, shock, and renal failure (USEPA 1977). $\mathrm{Cr}$ was equally found at elevated levels in the industrialized communities possibly due to anthropogenic activities and industrial processes. Exposure to $\mathrm{Cr}$ has been implicated to cause respiratory tract disorders. Shortness of breath, coughing, and wheezing were reported from a case of acute exposure to chromium, while perforations and ulcerations of the septum, bronchitis, decreased pulmonary function, pneumonia, and other respiratory effects have been noted from chronic exposure. Human studies have clearly established that inhaled chromium is a human carcinogen, resulting in an increased risk of lung cancer. Also, animal studies have shown chromium to cause lung tumors via inhalation exposure (USEPA 2007). Figure $2 a-n$ show the variability in the mean values of some of the physicochemical parameters from the different wells in the study area.

The presence of coliforms and E. coli in some of the water samples studied indicates that the water sources were fecally contaminated and could contain pathogens. This find- ing agrees with the report of Owamah et al. (2013) on the presence of coliform bacteria in groundwater sources of Isoko North communities, Nigeria. The ingestion of contaminated water in the study area could have led to the few reported cases of water borne diseases revealed by the respondents in the questionnaire survey (Table 5). The microorganisms isolated in this study include Enterobacteraerogenes, Citrobacter sp., Staphylococcus aureus, Klebsiella sp., Pseudomonas sp., Bacillus sp., Micrococcus sp., and Escherichia coli. Uzoigwe and Agwa (2012) in their reports on the bore-hole water quality in Port-Harcourt in Nigeria isolated similar microorganisms. The presence of indicator microorganisms is undesirable in drinking water. The presence of $E$. coli is of medical importance because its presence is an indication of the presence of other enteric pathogens. $E$. coli is known to cause many enteric diseases such as travelers' diarrhea and other forms of diarrhea (Obi and Okocha 2007). Other important pathogens identified are Pseudomonas, sp. Citrobacter sp., Klebsiella sp. and Enterobacteraerogenes. Bacillus sp., Staphylococcus sp., Staphylococcus sp., and are known to cause gastrointestinal disorders such as diarrhea (Obi and Okocha 2007). One of the limitations of this study is that the health data were self reported. Self-reported health data are always affected by human emotion and perception. However, results from the questionnaire survey appear to have a good correlation with health effects of the analyzed factors that exceeded standard limits. ANOVA clearly shows that water samples from hand-dug wells were the most polluted with the safest being the bore-hole water samples.

\section{Conclusion}

The findings of this study could serve as water quality database for the study area for future water project developments 
and further research. This study has shown that the drinking water samples in the area of study were contaminated with $\mathrm{Pb}, \mathrm{Ni}, \mathrm{Cr}$, and $\mathrm{Cd}$ and coliform bacteria. The microorganisms isolated in this study include Enterobacteriaceae, Staphylococcus aureus, Escherichia coli, Citrobacter, Klebsiella, Pseudomonas, Bacillus, and Micrococcus species. The bore-hole water samples were found to be relatively safer for drinking than hand-pump and dug-well water samples. Closeness of wells to septic tanks and the presence of industries in the area of study could be the reasons for the biological and metal contaminations, respectively. The relevant agencies should endeavor to provide potable water for the people. This study recommends public outreaches/workshops to notify people having wells with exceedance the danger of consuming water from such wells. Subsequent construction of wells in the study area should follow the rules for proper sitting of wells under the supervision of certified water engineers.

\section{References}

Afeni TB (2008) Assessment of flood control in an open pit mineSagamu experience. J Eng Appl Sci 3(9):708-717

APHA (1992) Standard methods for examination of water and wastewater, 18th edn. American Public Health Association, Washington, DC

APHA (2012) Standard methods for examination of water and wastewater, 22nd edn. American Public Health Association, Washington, DC

Dahunsi SO, Oranusi SU, Ishola RO (2012) Bioaccumulation pattern of cadmium and lead in the head capsule and body muscle of Clariasgariepinus [Burchell, 1822] exposed to paint emulsion effluent. Res J Environ Earth Sci 4(2):166-170

Domènech L, Saurí D (2011) A comparative appraisal of the use of rainwater harvesting in single and multifamily buildings of the Metropolitan Area of Barcelona (Spain): social experience, drinking water savings and economic costs. J Clean Prod 19:598-608

Khan S, Shahnaz M, Jehan N, Rehman S, Shah MT, Din I (2012) Drinking water quality and human health risk in Charsadda district, Pakistan. J Clean Prod. doi:10.1016/j.jclepro.2012.02.016
Mora A, Mac-Quhae C, Calzadilla M, Sanchez L (2009) Survey of trace metals in drinking water supplied to rural populations in the eastern Llanos of Venezuela. J Environ Manage 90:752-759

Obi CN, Okocha CO (2007) Microbiological and physicochemical analysis of elected bore-whole in World Bank Housing Estate, Umuahia, Abia State Nigeria. J Eng Appl Sci 2(5):920-929

Okorafor KA, Agbo BE, Johnson AM, Chiorhe M (2012) Physicochemical and bacteriological characteristics of selected steams and borehole in Akankpa and Calabar municipality, Nigeria. Arch Appl Sci Res 4(5):2115-2121

Owamah HI (2013) Biosorptive removal of $\mathrm{Pb}$ (II) and $\mathrm{Cu}(\mathrm{II})$ from wastewater using activated carbon from cassava peels. J Mater Cycles Waste Manag. doi10.1007/s10163-013-0192-z

Owamah HI, Asiagwu AK, Egboh SHO, Phil-Usiayo S (2013) Drinking water quality at Isoko North communities of the Niger Delta Region, Nigeria. Toxicol Environ Chem. doi:10.1080/02772248. 2013.847939

Shittu OB, Olaitan JO, Amusa TS (2009) Physicochemical and bacteriological analysis of water used for drinking and swimming in Abeokuta, Nigeria. Afr J Biomed Res 11:228-290

Tamasi G, Cini R (2004) Heavy metals in drinking waters from Mount Amiata(Tuscany, Italy). Possible risks from arsenic for public health in the Province of Siena. Sci Total Environ 327:41-51

Udoessien EI (2003) Basic principles of environmental science. Etiliew Ltd., Uyo

Ukpong EC, Okon BB (2013) Comparative analysis of public and private borehole water supply sources in Uruan Local Government Area of Akwa-Ibom State. Int J Appl Sci Technol 3(1):76-91

USEPA (1977) Toxicology of metals. In: Research environmental health effects series, vol II. United States Environmental Protection Agency, Washington, DC

USEPA (2007) Technology transfer network: chromium compounds. United States Environmental Protection Agency, Washington, DC

Uzoigwe CI, Agwa OK (2012) Microbiological quality of water collected from boreholes sited near refuse dumpsites in Port Harcourt, Nigeria. Afr J Biotechnol 11(13):3135-3139

WHO (1993) Guidelines for drinking water quality. In: Recommendations, vol. 1. World Health Organization, Geneva

WHO (1996) Guidelines for drinking water quality, vol II, 2nd edn. World Health Organization, Geneva

WHO (2006) Guidelines for drinking water quality, vol I, 3rd edn. Recommendations. First addendum to 3rd edition. World Health Organization, Geneva 